\title{
PEMBATASAN LUAS LAHAN USAHA PERKEBUNAN DALAM PERSPEKTIF HUKUM DI INDONESIA
}

\author{
Oleh \\ Ermanto Fahamsyah \\ Fakultas Hukum Universitas Jember, Jember \\ Email: ermanto.fahamsyah@gmail.com
}

\begin{abstract}
There is interrelation between a regulation on land area for agricultural purposes in one legislation and the similar issue in another. Therefore, it is important that these interrelated regulations be synchronized so that they can function compatibly with one another to ensure legal certainty, legal protection, justice, and prosperity among all parties concerned.
\end{abstract}

Keywords: Restriction, Area, Agriculture, Law

\begin{abstract}
Abstrak
Pengaturan luas lahan untuk usaha perkebunan dalam suatu peraturan perundangundangan tentunya akan terkait dengan peraturan perundang-undangan yang lain. Oleh karena itu, pengaturan hal tersebut harus seiring dan sejalan dengan peraturan perundang-undangan lain yang terkait agar tercipta adanya kepastian hukum, perlindungan hukum, keadilan dan kemakmuran bagi semua pihak yang berkepentingan.
\end{abstract}

Kata kunci: pembatasan, lahan, perkebunan, hukum.

\section{PENDAHULUAN}

Aspek hukum masalah tanah untuk usaha perkebunan menjadi penting untuk dibahas. Hal ini dikarenakan tanah sebagai salah satu sarana penting dalam usaha perkebunan. Salah satu aspek terkait masalah tanah yang penting untuk dikaji adalah pengaturan luas lahan untuk usaha perkebunan.

Pengaturan luas lahan untuk usaha perkebunan dalam suatu peraturan perundang-undangan tentunya akan terkait dengan peraturan perundang-undangan yang lain. Oleh karena itu, pengaturan hal tersebut harus seiring dan sejalan dengan peraturan perundang-undangan lain yang terkait agar tercipta adanya kepastian hukum, perlindungan hukum, keadilan dan kemakmuran bagi semua pihak yang berkepentingan. 


\section{PEMBAHASAN}

Usaha perkebunan memerlukan lahan yang relatif luas, sehingga hak atas tanah yang diberikan oleh Negara kepada perusahaan perkebunan salah satunya dalam bentuk Hak Guna Usaha (HGU). Terdapat beberapa dasar hukum terkait pengaturan HGU dan luas lahan untuk usaha perkebunan, antara lain:

\section{Undang-Undang Dasar 1945}

Pasal 33 UUD 1945 dikenal sebagai pasal ideologi dan politik ekonomi Indonesia, ${ }^{1}$ karena di dalamnya memuat ketentuan tentang hak penguasaan Negara atas cabang-cabang produksi yang penting bagi Negara dan yang menguasai hajat hidup orang banyak; dan bumi dan air dan kekayaan alam yang terkandung di dalamnya yang harus dipergunakan untuk sebesarbesarnya kemakmuran rakyat. ${ }^{2}$

Batang tubuh dan penjelasan UUD 1945 sendiri tidak memuat penjelasan mengenai sifat dan lingkup hak menguasai dari Negara yang meliputi bumi, air dan kekayaan alam yang terkandung di dalamnya. Hanya diberikan penegasan bahwa karena merupakan pokok-pokok kemakmuran rakyat, bumi, air dan kekayaan alam yang terkandung di dalamnya harus dikuasai oleh Negara. ${ }^{3}$

Dalam penjelasan Pasal 33 ayat (3) hanya dinyatakan bahwa:

\footnotetext{
${ }^{1}$ Pasal 33 UUD 1945 yang terdiri atas 3 ayat, dan telah menjadi ideologi dan politik ekonomi Indonesia, yang melalui perdebatan politik panjang dan alot dalam 2 kali sidang tahunan MPR (2001 dan 2002), telah di-amandemen menjadi 5 ayat sebagai berikut:

1. Perekonomian disusun sebagai usaha bersama berdasar atas asas kekeluargaan (lama)

2. Cabang-cabang produksi yang penting bagi negara dan yang menguasai hajat hidup orang banyak dikuasai oleh negara (lama)

3. Bumi dan air dan kekayaan alam yang terkandung di dalamnya dikuasai oleh negara dan dipergunakan untuk sebesar-besar kemakmuran rakyat (lama)

4. Perekonomian nasional diselenggarakan berdasar atas demokrasi ekonomi dengan prinsip kebersamaan, efisiensi berkeadilan, berkelanjutan, berwawasan lingkungan, kemandirian, serta dengan menjaga keseimbangan kemajuan dan kesatuan ekonomi nasional. (Perubahan Keempat)

5. Ketentuan lebih lanjut mengenai pelaksanaan pasal ini diatur dalam undang-undang. (Perubahan Keempat).

2 Pasal 33 ayat (3) secara khusus dan tegas menggariskan kebijakan dasar mengenai penguasaan dan penggunaan sumber-sumber daya alam yang ada.

3 Boedi Harsono, Hukum Agraria Indonesia, cet. XIX, (Jakarta: Djambatan, 2008), hal. XXXV.
} 
Bumi dan air dan kekayaan alam yang terkandung di dalamnya dikuasai oleh Negara dan dipergunakan untuk sebesar-besar kemakmuran rakyat. Sebab itu harus dikuasai oleh Negara dan dipergunakan untuk sebesarbesar kemakmuran rakyat.

Baru dengan kelahiran Undang-Undang Nomor 5 Tahun 1960 tentang Peraturan Dasar Pokok-Pokok Agraria, yang selanjutnya disebut UUPA, ${ }^{4}$ diberikan penjelasan resmi mengenai sifat dan lingkup Hak Menguasai dari Negara tersebut. ${ }^{5}$

Pernyataan tersebut merumuskan isi konsepsi khas Hukum Agraria Nasional Indonesia, yang dikenal sebagai konsepsi komunalistik religius, yang menegaskan hubungan kepunyaan bersama rakyat atau bangsa Indonesia dengan bumi, air, ruang angkasa, dan kekayaaan alam yang terkandung di dalamnya yang bersifat perdata, tetapi bukan hubungan pemilikan. Sekaligus mengandung unsur hubungan publik dalam rangka mewujudkan amanat dalam Pembukaan Undang-Undang Dasar Republik Indonesia 1945. Dalam rangka mewujudkan amanat itulah, Negara Republik Indonesia diberikan serangkaian kewenangan, yang dirumuskan dalam Pasal UUPA, yang menegaskan sifat publik sekaligus lingkup hak menguasai dari Negara yang dimaksudkan dalam Pasal 33 ayat (3) UUD $1945 .^{6}$

Atas dasar ketentuan Pasal 33 ayat (3) UUD 1945, bumi, air dan ruang angkasa, termasuk kekayaan alam yang terkandung di dalamnya itu pada tingkatan tertinggi dikuasai oleh Negara, sebagai organisasi kekuasaan

\footnotetext{
${ }^{4}$ Indonesia, Peraturan Dasar Pokok-Pokok Agraria, UU No. 5 Tahun 1960, LN No. 104 Tahun 1960, TLN No. 2043.

${ }^{5}$ Boedi Harsono, Op.Cit, hal. XXXV. Kaitan dengan hak menguasai dari Negara bisa dilihat pada ketentuan Pasal 1 ayat (1) dan (2) UUPA, yang menyebutkan: "Seluruh wilayah Indonesia adalah kesatuan tanah air dari seluruh rakyat Indonesia, yang bersatu sebagai bangsa Indonesia", "Seluruh bumi, air dan ruang angkasa, termasuk kekayaan alam yang terkandung di dalamnya dalam wilayah Republik Indonesia sebagai karunia Tuhan Yang Maha Esa adalah bumi, air dan ruang angkasa bangsa Indonesia merupakan kekayaan nasional". Lihat dalam Indonesia, Peraturan Dasar Pokok-Pokok Agraria, pasal 1 ayat (1) dan (2).

${ }^{6}$ Boedi Harsono, Op. Cit., hal. XXXVI.
} 
seluruh rakyat. ${ }^{7}$ Hak Menguasai dari Negara yang dimaksud meliputi kewenangan untuk mengatur dan menyelenggarakan peruntukan, penggunaan persediaan dan pemeliharaan bumi, air dan ruang angkasa Indonesia; menentukan dan mengatur hubungan hukum antara orang-orang dengan bumi, air dan ruang angkasa tersebut; serta menentukan dan mengatur hubungan hukum antara orang-orang dan perbuatan hukum mengenai bumi, air dan ruang angkasa tersebut. ${ }^{8}$ Wewenang yang bersumber pada hak menguasai dari Negara tersebut digunakan untuk mencapai sebesar-besarnya kemakmuran rakyat dalam arti kebangsaan, kesejahteraan, dan kemerdekaan dalam masyarakat dan Negara hukum Indonesia yang merdeka, berdaulat, adil dan makmur. ${ }^{9}$

Dikuasai oleh Negara dalam Pasal 33 UUD 1945 tidak berarti Negara sendiri menjadi pengusaha, usahawan atau ondernemer. Lebih tepat dikatakan bahwa kekuasaan Negara terdapat pada membuat peraturan guna melancarkan jalan ekonomi, peraturan yang melarang pula "pengisapan” orang yang lemah oleh orang lain yang bermodal. ${ }^{10}$ Dengan demikian, penafsiran dari kalimat "dikuasai oleh Negara" dalam ayat (2) dan (3) Pasal 33 UUD 1945 tidak selalu dalam bentuk kepemilikan, tetapi utamanya dalam bentuk kemampuan untuk melakukan kontrol dan pengaturan serta memberikan pengaruh agar

${ }^{7}$ Indonesia, Peraturan Dasar Pokok-Pokok Agraria, Pasal 2 ayat (1). Pasal 2 ayat (1) kembali menyebutkan dan menegaskan pernyataan dalam Pasal 33 ayat (3) UUD 1945 dan selanjutnya menjadi dasar pembentukkan Pasal 2 ayat (2) UUPA yang mengatur mengenai hak menguasai dari Negara.

${ }^{8}$ Ibid., Pasal 2 ayat (2). Hak menguasai Negara sebagaimana diatur dalam Pasal 2 ayat (2) UUPA merupakan perwujudan kehendak dari ketentuan dasar yang terkandung dalam dalam Pasal 1 ayat (2), yang menyatakan: "seluruh air, bumi, dan ruang angkasa termasuk kekayaan alam yang terkandung di dalamnya dalam wilayah Kepulauan Indonesia itu merupakan kekayaan nasional sebagai karunia Tuhan YME kepada Bangsa Indonesia".

${ }^{9}$ Ibid., Pasal 2 ayat (3).

10 Mohammad Hatta, "Cita-cita Kooperasi dalam Pasal 33 UUD 1945," Pidato Hari Kooperasi, 12 Juli 1977, dalam Sri-Edi Swasono dan Fauzie Ridzal, Penyunting, Satu Abad Bung Hatta-Demokrasi Kita, Bebas Aktif, Ekonomi Masa Depan (Jakarta: UI-Press, 2006), hal. 225. 
perusahaan tetap berpegang pada azas kepentingan mayoritas masyarakat dan sebesar-besarnya kemakmuran rakyat. ${ }^{11}$

Bentuk hak menguasai dari Negara sebagaimana tersebut di atas salah satunya diwujudkan dengan melakukan pengaturan mengenai penggunaan hak atas tanah dalam bentuk Hak Guna Usaha, selanjutnya disingkat HGU. ${ }^{12}$ Pengaturan penggunaan hak atas tanah dalam bentuk HGU tersebut ditujukan untuk mewujudkan masyarakat yang adil, makmur dan sejahtera.

2. Undang-Undang Nomor 5 Tahun 1960 tentang Peraturan Dasar Pokok-Pokok Agraria (UUPA)

UUPA merupakan salah satu dasar untuk membuat atau membentuk pengaturan yang berhubungan dengan penggunaan dan penguasaan hak atas tanah. Pasal 2 ayat (2) dan (3) UUPA memuat ketentuan bahwa semua peraturan perundang-undangan yang mengatur peruntukan, penggunaan, persediaan dan pemeliharaan tanah harus digunakan untuk mencapai kemakmuran rakyat yang sebesar-besarnya, dalam arti kebahagiaan, kesejahteraan dan kemerdekaan dalam masyarakat dan Negara Hukum Indonesia yang merdeka berdaulat, adil dan makmur.

Ketentuan Hak Guna Usaha dalam UUPA terdapat dalam Pasal 28-34. Hak Guna Usaha adalah hak untuk mengusahakan tanah yang dikuasai langsung oleh Negara, dalam jangka waktu tertentu guna perusahaan pertanian, perikanan atau peternakan. ${ }^{13}$ Hak Guna Usaha diberikan atas tanah yang luasnya paling sedikit 5 (lima) hektar, dengan ketentuan jika luasnya 25 (dua puluh lima) hektar atau lebih harus memakai investasi modal yang layak dan teknik perusahaan yang baik, sesuai dengan perkembangan zaman. ${ }^{14}$

${ }^{11}$ Arimbi HP dan Emmy Hafild, "Membumikan Mandat Pasal 33 UUD 45", [http://www.pacific.net.id/ dede_s/Membumikan.htm], diakses 16 Mei 2009.

\footnotetext{
${ }^{12}$ Pembahasan Hak Guna Usaha dalam usaha perkebunan menjadi penting dikarenakan usaha perkebunan yang diselenggarakan oleh perusahaan perkebunan besar swasta dan Negara memerlukan lahan yang relatif luas, sehingga hak atas tanah yang diberikan dalam bentuk Hak Guna Usaha.

${ }^{13}$ Indonesia, Peraturan Dasar Pokok-Pokok Agraria, Pasal 28 ayat (1).

${ }^{14}$ Ibid., Pasal 28 ayat (2).
} 
Hak Guna Usaha berdasarkan ketentuan UUPA diberikan dalam jangka waktu paling lama 25 (dua puluh lima) tahun dan untuk perusahaan yang memerlukan jangka waktu lebih lama diberikan jangka waktu paling lama 35 (tiga puluh lima) tahun dan jangka waktu tersebut dapat diperpanjang paling lama 25 (dua puluh lima) tahun atas permintaan pemegang hak dan mengingat keadaan perusahaannya. ${ }^{15}$

Menurut sifat dan tujuannya, HGU adalah hak yang waktu berlakunya terbatas. Jangka waktu 25 (dua puluh lima) atau 35 tahun dengan kemungkinan diperpanjang dengan 25 (dua puluh lima) tahun dipandang sudah cukup lama untuk keperluan pengusahaan tanaman-tanaman yang berumur panjang. Penetapan jangka waktu 35 (tiga puluh lima) tahun, misalnya, mengingat pada tanaman kelapa sawit. ${ }^{16}$

3. Dalam masa reformasi ini, sumber daya agraria/sumber daya alam, yang di dalamnya juga termasuk tanah, harus dikelola dan dimanfaatkan secara optimal bagi generasi sekarang dan generasi mendatang dalam rangka mewujudkan masyarakat adil dan makmur. Hal ini sesuai amanat TAP MPR RI Nomor IX/MPR/2001 tentang Pembaruan Agraria dan Pengelolaan Sumber Daya Alam.

Pembaruan agraria mencakup suatu proses yang berkesinambungan berkenaan dengan penataan kembali penguasaan, pemilikan, penggunaan dan pemanfaatan sumber daya agraria, dilaksanakan dalam rangka tercapainya kepastian dan perlindungan hukum serta keadilan dan kemakmuran bagi seluruh rakyat Indonesia (Pasal 2).

4. UU Nomor 25 Tahun 2007 tentang Penanaman Modal tidak mengatur secara khusus mengenai luas lahan untuk kegiatan penanaman modal atau kegiatan usaha, termasuk usaha perkebunan. Akan tetapi, hanya mengatur tentang pelayanan dan/atau perizinan hak atas penanam modal dalam Pasal 22, dimana hak atas tanah sebagaimana dimaksud dapat diberikan dan

\footnotetext{
${ }^{15}$ Ibid., Pasal 29 ayat (1), (2), (3).

${ }^{16}$ Ibid., Penjelasan Pasal 29.
} 
diperpanjang di muka sekaligus dan dapat diperbarui kembali atas permohonan penanam modal. ${ }^{17}$ Untuk Hak Guna Usaha dapat diberikan dengan jumlah 95 (sembilan puluh lima) tahun dengan cara dapat diberikan dan diperpanjang di muka sekaligus selama 60 (enam puluh) tahun dan dapat diperbarui selama 35 (tiga puluh lima) tahun. ${ }^{18}$ Hak Guna Usaha diperoleh dengan cara dapat diberikan dan diperpanjang di muka sekaligus selama 60 (enam puluh) tahun dan dapat diperbarui selama 35 (tiga puluh lima) tahun. ${ }^{19}$ Pemberian dan perpanjangan di muka sekaligus tersebut dengan persyaratanpersyaratan sebagai berikut. Penanaman modal yang dilakukan dalam jangka panjang dan terkait dengan perubahan struktur perekonomian Indonesia yang lebih berdaya saing; Penanaman modal dengan tingkat resiko penanaman modal yang memerlukan pengembalian modal dalam jangka panjang sesuai dengan jenis kegiatan penanaman modal yang dilakukan; Penanaman modal yang tidak memerlukan areal yang luas; Penanaman modal dengan menggunakan hak atas tanah Negara; Penanaman modal yang tidak mengganggu rasa keadilan masyarakat dan tidak merugikan kepentingan umum. $^{20}$

Undang-Undang Penanaman Modal selanjutnya menentukan bahwa Hak Guna Usaha dapat diperbarui setelah dilakukan evaluasi bahwa tanahnya masih digunakan dan diusahakan dengan baik sesuai dengan keadaan, sifat, dan tujuan pemberian hak. ${ }^{21}$ Artinya, pembaharuan hak atas tanah berupa

${ }^{17}$ Indonesia, Undang-Undang Penanaman Modal, UU No. 25 Tahun 2007, LN No. 67 Tahun 2007, TLN No. 4724.

${ }^{18}$ Ibid., Pasal 22 ayat (1) huruf a.

Dalam perdebatan di Parlemen mengenai Rancangan Undang-undang Investasi yang menggantikan UU No. 1 Tahun 1967 tentang PMA dan UU No. 5 Tahun 1968 tentang PMDN, bulan Maret 2007. Pemerintah Indonesia dan para anggota DPR, kecuali Fraksi PDIP, setuju tentang pemberian dan perpanjangan hak atas tanah bagi investor diberikan pada saat yang sama. Setelah jangka waktu itu berjalan, melalui proses evaluasi, hak atas tanah tersebut dapat diperbaharui. Lihat dalam Erman Rajagukguk, et al., Masalah Tanah Di Indonesia Dari Masa Ke Masa, (Jakarta: Lembaga Studi Hukum Ekonomi Fakultas Hukum Universitas Indonesia, 2007), hal. 38-39.

\footnotetext{
${ }^{19}$ Indonesia, Undang-Undang Penanaman Modal, Penjelasan Pasal 22 ayat (1) huruf a.

${ }^{20}$ Ibid., Pasal 22 ayat (2).

${ }^{21}$ Ibid., Pasal 22 ayat (3).
} 
HGU tersebut baru diberikan setelah diadakan evaluasi, yaitu setelah 60 (enam puluh) tahun. Adalah salah pengertian apabila dikatakan hak-hak tersebut diberikan di muka sekaligus seperti dalam ketentuan Peraturan Pemerintah Nomor 40 Tahun $1996{ }^{22}$

Di samping itu, pemberian dan perpanjangan Hak Guna Usaha yang diberikan sekaligus di muka dan yang dapat diperbarui tersebut dapat dihentikan atau dibatalkan oleh Pemerintah jika perusahaan penanaman modal menelantarkan tanah, merugikan kepentingan umum, menggunakan atau memanfaatkan tanah tidak sesuai dengan maksud dan tujuan pemberian hak atas tanahnya, serta melanggar ketentuan peraturan perundang-undangan di bidang pertanahan. $^{23}$

Pengaturan pemberian fasilitas HGU dalam UU Penanaman Modal kepada investor yang bergerak pada bidang pertanian, termasuk investor di perkebunan, tentunya dengan harapan dapat lebih memberikan kesempatan kepada para petani kecil dalam penggunaan tanah untuk usaha dalam bidang pertanian. Pernyataan ini sesuai dengan pendapat dari Bungaran Saragih dalam Sidang Perkara Nomor 21/PUU-V/2007 Perihal Pengujian UndangUndang Republik Indonesia Nomor 25 Tahun 2007 Tentang Penanaman Modal Terhadap UUD 1945 yang mengemukakan:

Tidaklah tepat bila dikatakan Undang-Undang Penanaman Modal akan menelantarkan petani kecil, bahkan menurut pendapat saya UndangUndang Penanaman Modal ini yang memfasilitasi adanya HGU pada sektor pertanian justru dapat memberi kesempatan kepada petani kecil melalui program inti plasma. Dalam program inti plasma paling sedikit $20 \%$ dari HGU harus diberikan kepada petani plasma, bahkan ada perusahaan yang secara sukarela arealnya itu 60\% diberikan kepada petani plasma. Dalam artian, melalui program inti plasma $20 \%$ sampai $60 \%$ lahan perkebunan dalam bentuk HGU itu diberikan kepada petani plasma, intinya dalam bentuk HGU tetap, tetapi lahan-lahan plasma itu

${ }^{22}$ Erman Rajagukguk, et al., Masalah Tanah Di Indonesia Dari Masa Ke Masa, hal. 40. Selanjutnya lihat juga PP 40 Tahun 1996 yang memuat ketentuan hak atas tanah bagi investor.

${ }^{23}$ Indonesia, Undang-Undang Penanaman Modal, Pasal 22 ayat (4). 
tidak dalam bentuk HGU tetapi menjadi hak milik, hak milik jauh lebih kuat daripada $\mathrm{HGU}^{24}$

Namun demikian, melalui Putusan Mahkamah Konstitusi Republik Indonesia Nomor 21/PUU-V/2007 Perihal Pengujian Undang-Undang Republik Indonesia Nomor 25 Tahun 2007 Tentang Penanaman Modal Terhadap Undang-Undang Dasar 1945, ketentuan-ketentuan dalam UU Penanaman Modal yang berkaitan dengan HGU yaitu Pasal 22 Ayat (1) sepanjang menyangkut kata-kata “di muka sekaligus”, Pasal 22 Ayat (2) sepanjang menyangkut kata-kata "di muka sekaligus" dan Pasal 22 Ayat (4) sepanjang menyangkut kata-kata "sekaligus di muka" dalam perkembangannya dinyatakan bertentangan dengan UUD 1945 dan tidak mempunyai kekuatan hukum mengikat. $^{25}$

5. Penggunaan HGU untuk usaha perkebunan secara khusus diatur dalam Undang-Undang Nomor 18 Tahun 2004 tentang Perkebunan, selanjutnya disebut UU Perkebunan. ${ }^{26}$ Menurut UU Perkebunan, pembangunan perkebunan dilakukan dalam rangka mewujudkan kemakmuran dan kesejahteraan rakyat secara berkeadilan sebagaimana diamanatkan dalam UUD $1945 .{ }^{27}$ Untuk dapat mewujudkan hal tersebut, perlu dilakukan suatu pengaturan mengenai kegiatan perkebunan dalam UU Perkebunan.

Penggunaan tanah untuk usaha perkebunan, terutama mengenai HGU, merupakan salah satu permasalahan yang diatur dalam UU Perkebunan. ${ }^{28} \mathrm{UU}$

\footnotetext{
${ }^{24}$ Lihat dalam Bungaran Saragih, Risalah Sidang Perkara Nomor 21/PUU-V/2007 Perihal Pengujian Undang-Undang Republik Indonesia Nomor 25 Tahun 2007 Tentang Penanaman Modal Terhadap Undang-Undang Dasar 1945, Acara Mendengar Keterangan Ahli Dari Pemohon Dan Pemerintah (IV), Jakarta, 20 Nopember 2007, hal. 37-40.

${ }^{25}$ Putusan Mahkamah Konstitusi Republik Indonesia Nomor 21-22/PUU-V/2007 Perihal Pengujian Undang-Undang Republik Indonesia Nomor 25 Tahun 2007 Tentang Penanaman Modal Terhadap Undang-Undang Dasar 1945.

${ }^{26}$ Indonesia. Undang-Undang Perkebunan. UU No. 18 Tahun 2004, LN No. 85 Tahun 2004, TLN No. 4411. Dalam pertimbangan UU Perkebunan tersebut tidak mengacu pada UUPA, khususnya yang berkaitan dengan HGU.

${ }^{27}$ Ibid., bagian Menimbang huruf a.

${ }^{28}$ Penggunaan tanah untuk usaha perkebunan diatur dalam Bab III, Pasal 9 sampai dengan Pasal 12 UU Perkebunan.
} 
Perkebunan mengatur bahwa pelaku usaha perkebunan sesuai dengan kepentinganya dapat memperoleh hak atas tanah, ${ }^{29}$ salah satunya dalam bentuk HGU, ${ }^{30}$ dengan luas maksimum dan luas minimumnya ditetapkan oleh Menteri. ${ }^{31}$ Pengaturan batas luas maksimum dan minimum tersebut guna menjamin pemilikan, penguasaan, penggunaan dan pemanfaatan tanah secara berkeadilan. $^{32}$

HGU diberikan dalam jangka waktu paling lama 35 tahun dan dapat diperpanjang selama 25 tahun berdasarkan penilaian Menteri serta dapat diperbarui. ${ }^{33}$ Pengaturan mengenai harus adanya penilaian dari Menteri dimaksudkan untuk memberikan kepastian usaha bagi perusahaan perkebunan yang secara nyata dan beritikad baik dalam mengelola usaha perkebunan, sehingga memberikan keuntungan bagi pelaku usaha, masyarakat sekitar dan Negara. $^{34}$

Meskipun pelaku usaha sudah mendapatkan persetujuan untuk mendapatkan HGU dari Pemerintah. Namun demikian, Pemerintah dapat menghapus HGU yang telah diberikan kepada pelaku usaha perkebunan tersebut, apabila menurut penilaian HGU tersebut tidak dimanfaatkan sesuai dengan rencana yang dipersyaratkan dan ditelantarkan selama tiga tahun berturut-turut sejak diberikannya HGU yang bersangkutan. ${ }^{35}$

Adapun luasan tanah tertentu untuk usaha budi daya tanaman perkebunan dan kapasitas pabrik tertentu untuk usaha industri pengelolaan hasil perkebunan

\footnotetext{
${ }^{29}$ Pemberian hak atas tanah untuk usaha perkebunan harus tetap memperhatikan hak ulayat masyarakat hukum adat, sepanjang menurut kenyataannya masih ada dan tidak bertentangan dengan hukum yang lebih tinggi serta kepentingan nasional. Lihat dalam Indonesia. UndangUndang Perkebunan, Pasal 9 ayat (2) dan Penjelasan Umum.

${ }^{30}$ Selain HGU, pelaku usaha perkebunan juga dapat memperoleh hak guna bangunan dan hak pakai. Lihat dalam Indonesia, Undang-Undang Perkebunan, Pasal 9 ayat (1).

${ }^{31}$ Ibid., Pasal 9 dan 10.

${ }^{32}$ Ibid., Penjelasan Umum.

${ }^{33}$ Ibid., Pasal 11.

${ }^{34}$ Ibid., Penjelasan Pasal 11 ayat (2).

${ }^{35}$ Ibid., Pasal 12.
} 
ditetapkan oleh Menteri berdasarkan jenis tanaman, teknologi, tenaga kerja, dan modal. ${ }^{36}$ Menteri yang dimaksud adalah Menteri yang tugas dan tanggung jawabnya di bidang perkebunan, dalam hal ini Menteri Pertanian. ${ }^{37}$ Sebagai tindak lanjut amanat tersebut, terbit Peraturan Menteri Pertanian Nomor 26/Permentan/OT.140/2/2007 tentang Pedoman Perizinan Usaha Perkebunan. ${ }^{38}$ Pada tahun 2013, Permentan Nomor 26 Tahun 2007 tersebut ditinjau kembali dengan terbitnya Peraturan Menteri Pertanian Nomor 98/Permentan/OT.140/9/2013 tentang Pedoman Perizinan Usaha Perkebunan.

6. Peraturan Pemerintah Nomor 40 Tahun 1996 tentang Hak Guna Usaha (HGU), Hak Guna Bangunan (HGB) dan Hak Pakai Atas Tanah, selanjutnya disebut PP 40/1996. ${ }^{39}$ PP 40 Tahun 1996 merupakan peraturan pelaksanaan yang diamanatkan oleh Pasal 50 ayat (2) UUPA. PP tersebut memuat ketentuan lebih lanjut mengenai hak-hak atas tanah yang diatur dalam Pasal 16 UUPA, khususnya mengenai Hak GunaUsaha, Hak Guna Bangunan dan Hak Pakai. $^{40}$

HGU hanya dapat diberikan kepada Warga Negara Indonesia dan badan hukum yang didirikan menurut Hukum Indonesia dan berkedudukan di Indonesia. $^{41}$ Hal ini menegaskan bahwa hanya WNI atau Badan Hukum Indonesia yang dapat mempunyai hak atas tanah, termasuk HGU.

\footnotetext{
${ }^{36}$ Ibid., Pasal 17 ayat (3).

${ }^{37}$ Berdasarkan ketentuan Pasal 1 angka 14.

${ }^{38}$ Peraturan Menteri Pertanian Nomor 26 Tahun 2007 tentang Pedoman Perizinan Usaha Perkebunan diterbitkan dengan pertimbangan adanya perkembangan usaha di bidang perkebunan; sebagai tindak lanjut Pasal 10 (1), 17 (3), 17 (7), 22 (3) UU Nomor 18 Tahun 2004 tentang Perkebunan; dan untuk mencabut Keputusan Menteri Pertanian Nomor 357/KPTS/HK.350/5/2002 tentang Pedoman Perizinan Usaha Perkebunan.

Hal ini menunjukkan bahwa Permentan Nomor 26 Tahun 2007 merupakan pengaturan lebih lanjut dari beberapa pasal dalam UU Perkebunan, terutama pasal yang menyangkut tentang penggunaan tanah untuk usaha perkebunan, pemberian ijin usaha perkebunan dan pola kemitraan usaha perkebunan.

${ }^{39}$ Indonesia, Peraturan Pemerintah tentang Hak Guna Usaha, Hak Guna Bangunan dan Hak Pakai Atas Tanah, PP No. 40 Tahun 1996, LN No. 58 Tahun 1996, TLN No. 3643.

${ }^{40}$ Ibid., Penjelasan Umum. Khusus mengenai HGU diatur secara rinci dalam Pasal 2 sampai dengan 18 Peraturan Pemerintah Nomor 40 Tahun 1996.
}

${ }^{41}$ Ibid., Pasal 2. 
Peraturan Pemerintah Nomor 40 Tahun 1996 juga memuat secara jelas tentang Kewajiban dan Hak Pemegang HGU, yang belum diatur dalam UUPA. Kewajiban pemegang HGU diantaranya melaksanakan usaha pertanian, perkebunan, perikanan dan/atau peternakan sesuai peruntukkan dan persyaratan sebagaimana ditetapkan dalam keputusan pemberian haknya. ${ }^{42}$ Sedangkan hak pemegang HGU diantaranya adalah menguasai dan mempergunakan tanah yang diberikan HGU untuk melaksanakan usaha di bidang pertanian, perkebunan, perikanan dan/atau peternakan. ${ }^{43}$

Hal tersebut menunjukkan bahwa HGU diberikan oleh Negara Indonesia kepada WNI atau Badan Hukum Indonesia untuk kegiatan usaha di bidang pertanian, perkebunan dan/atau peternakan. Namun demikian, HGU tersebut tentunya juga harus mempunyai fungsi sosial sehingga akan tercapai tujuan pokok yaitu kemakmuran, keadilan dan kebahagiaan bagi rakyat seluruhnya.

7. Pasal 12 ayat (1) Peraturan Menteri Pertanian Nomor 26/Permentan/OT. 140/2/2007 tentang Pedoman Perizinan Usaha Perkebunan menentukan bahwa Izin Usaha Perkebunan (IUP) untuk 1 (satu) perusahaan diberikan dengan batas paling luas berdasarkan jenis komoditas sebagaimana tercantum dalam Lampiran 3 Peraturan ini. Antara lain, untuk kelapa sawit 100.000 hektar, karet 25.000 hektar, dan tebu 150.000 hektar.

Pasal 12 Ayat (2) menentukan bahwa batasan paling luas sebagaimana dimaksud di atas tidak berlaku untuk:

a. Perusahaan perkebunan yang pemegang saham mayoritasnya Koperasi Usaha Perkebunan;

b. Perusahaan perkebunan yang sebagian besar atau seluruh saham dimiliki oleh Negara baik Pemerintah, Propinsi atau Kabupaten/Kota;

c. Perusahaan perkebunan yang sebagian besar sahamnya dimiliki oleh masyarakat dalam rangka go public.

\footnotetext{
${ }^{42}$ Ibid., Pasal 12 ayat (1) huruf b.

${ }^{43}$ Ibid., Pasal 13 ayat (1).
} 
Selanjutnya Pasal 12 Ayat (3) menentukan batas luasan areal usaha budidaya perkebunan di Propinsi Papua paling luas 2 (dua) kali dari batasan sebagaimana dimaksud pada ayat (1) .

8. Salah satu ketentuan lain yang penting untuk dicermati dalam Permentan Nomor 26 Tahun 2007 diantaranya ketentuan Pasal 11. Pasal 11 mengatur bahwa perusahaan perkebunan yang memiliki Izin Usaha Perkebunan (IUP) dan Izin Usaha Perkebunan Budidaya (IUP-B), wajib membangun kebun untuk masyarakat sekitar paling rendah seluas $20 \%$ dari total luas areal kebun yang diusahakan oleh perusahaan. Pembangunan kebun untuk masyarakat sebagaimana dimaksud dapat dilakukan antara lain melalui pola kredit, hibah atau bagi hasil. Pembangunan kebun untuk masyarakat tersebut dilakukan bersamaan dengan pembangunan kebun yang diusahakan oleh perusahaan. ${ }^{44}$ Adanya ketentuan Pasal 11 Permentan 26 Tahun 2007 di atas menunjukkan bahwa luas areal yang dimiliki oleh perusahaan perkebunan (dalam bentuk HGU) tidak hanya dikuasai sendiri oleh perusahaan, tetapi perusahaan harus berbagi kepada masyarakat. Tujuan membangunkan kebun seluas minimal $20 \%$ dari total lahan yang dimiliki perusahaan perkebunan tidak lain agar petani atau masyarakat di sekitar perkebunan menikmati kesejahteraan dengan adanya kegiatan usaha perkebunan. Sehingga dampak sosial dari kesenjangan sosial ekonomi bisa dihindari.

Dengan demikian, jelas bahwa pengaturan lebih lanjut penggunaan tanah untuk usaha perkebunan, pemberian ijin usaha perkebunan dan pola kemitraan usaha perkebunan dalam Peraturan Menteri Pertanian Nomor 26 tahun 2007 dipandang dari segi filosofis diharapkan dapat mewujudkan adanya kepastian hukum, keadilan dan kesejahteraan masyarakat; dari segi yuridis, untuk mengatur lebih lanjut apa yang telah diatur dalam UU Nomor 18 Tahun 2004 tentang Perkebunan; dari segi sosiologis, melalui pengaturan kegiatan perkebunan secara jelas, tegas dan lugas lagi dalam Permentan dimaksudkan untuk memberikan keuntungan ekonomi bagi para pelaku usaha

44 Peraturan Menteri Pertanian Nomor 26/Permentan/OT.140/2/2007 tentang Pedoman Perizinan Usaha Perkebunan, Pasal 11 ayat (1), (2), dan (3). 
perkebunan sekaligus juga untuk memberikan kesejahteraan kepada masyarakat sekitar perkebunan serta Negara secara luas. Sehingga tujuan penyelenggaraan perkebunan untuk meningkatkan pendapatan masyarakat; meningkatkan penerimaan Negara; meningkatkan penerimaan devisa Negara; menyediakan lapangan pekerjaan; meningkatkan produktivitas, nilai tambah dan daya saing; memenuhi kebutuhan konsumsi dan bahan baku industri dalam negeri; dan mengoptimalkan pengelolaan sumber daya alam secara berkelanjutan diharapkan dapat tercapai secara maksimal.

Pada akhirnya, penerbitan Permentan Nomor 26 Tahun 2007 tersebut dapat dikatakan sebagai sarana untuk menciptakan kepastian hukum, keadilan dan kemanfaatan/kesejahteraan bagi semua pihak yang berkepentingan dalam pembangunan dan pengelolaan usaha perkebunan dan bangsa Indonesia secara luas.

9. Sebelum diatur secara khusus dalam Permentan Nomor 26 Tahun 2007, mengenai luas lahan untuk usaha perkebunan telah diatur dalam Keputusan Menteri Kehutanan dan Perkebunan Nomor 107/Kpts-II/1999 tentang Perizinan Usaha Perkebunan, khususnya dalam Pasal 4 yang menentukan:

a. Luas maksimum lahan usaha perkebunan besar, kecuali usaha perkebunan tebu, adalah 20.000 hektar dalam satu propinsi atau 100.000 hektar untuk seluruh Indonesia;

b. Luas maksimum lahan usaha perkebunan tebu adalah 60.000 hektar dalam satu propinsi atau 150.000 hektar untuk seluruh Indonesia;

c. Luas maksimum lahan usaha perkebunan besar khusus di Propinsi Irian Jaya adalah 2 (dua) kali luas maksimum lahan usaha perkebunan besar di propinsi lainnya sebagaimana dimaksud dalam butir a dan $b$.

10. Selanjutnya untuk meninjau kembali Keputusan Menteri Kehutanan dan Perkebunan Nomor 107/Kpts-II/1999, telah diterbitkan Keputusan Menteri Pertanian Nomor 357/Kpts/HK.350/5/2002 tentang Pedoman Perizinan Perkebunan yang dalam Pasal 7 juga mengatur tentang luas lahan untuk usaha budidaya perkebunan. Luas lahan usaha budidaya perkebunan untuk satu perusahaan atau grup perusahaan ditetapkan sebagi berikut : 
a. Luas maksimum lahan usaha perkebunan adalah 20.000 hektar dalam satu propinsi atau 100.000 hektar untuk seluruh Indonesia, kecuali usaha perkebunan tebu.

b. Luas maksimum lahan usaha perkebunan tebu adalah 60.000 hektar dalam satu propinsi atau 150.000 hektar untuk seluruh Indonesia.

Luas maksimum untuk usaha budidaya perkebunan, sebagaimana dimaksud di atas tidak berlaku bagi perusahaan perkebunan yang pemegang saham mayoritasnya Koperasi Usaha Perkebunan; perusahaan perkebunan yang sebagian atau seluruh sahamnya dimiliki oleh Negara, baik Pemerintah maupun Propinsi, Kabupaten atau Kota.

11. Terakhir, Peraturan Menteri Pertanian Nomor 98/Permentan/OT.140/9/2013 tentang Pedoman Perizinan Usaha Perkebunan yang merupakan hasil peninjauan kembali terhadap Peraturan Menteri Pertanian Nomor 26/Permentan/OT.140/2/2007.

Permentan Nomor 98 Tahun 2013 juga memuat ketentuan tentang batasan luas lahan untuk usaha perkebunan. Pasal 17 ayat (1) menentukan bahwa Izin Usaha Perkebunan untuk Budidaya (IUUP-B) sebagaimana dimaksud dalam Pasal 8, untuk 1 (satu) Perusahaan atau Kelompok (Group) Perusahaan Perkebunan diberikan dengan batas paling luas berdasarkan jenis tanaman sebagaimana tercantum dalam Lampiran $\mathrm{V}$ yang merupakan bagian tidak terpisahkan dari Peraturan ini. Pasal 17 ayat (2) menentukan bahwa Izin Usaha Perkebunan sebagaimana dimaksud dalam Pasal 10 ayat (2), untuk 1 (satu) Perusahaan atau Kelompok (Group) Perusahaan Perkebunan diberikan dengan batas paling luas untuk tanaman kelapa sawit 100.000 hektar, teh 20.000 hektar dan tebu 150.000 hektar. Selanjutnya, Pasal 17 ayat 3 menyebutkan bahwa batas paling luas sebagaimana dimaksud pada ayat (1) dan ayat (2) tidak berlaku untuk Badan Usaha Milik Negara, Badan Usaha Milik Daerah, Koperasi dan perusahaan perkebunan dengan status perseroan terbuka (go public) yang sebagian besar sahamnya dimiliki oleh masyarakat. Pasal 17 ayat (4) menentukan batas luas sebagaimana dimaksud pada ayat (3) 
merupakan jumlah dari izin usaha perkebunan untuk 1 (satu) jenis tanaman perkebunan.

Berdasarkan penjelasan di atas menunjukkan bahwa peraturan perundang-undangan yang ada, khususnya yang mengatur tentang pertanahan atau yang di dalamnya memuat ketentuan tentang pertanahan dan peraturan pelaksanaannya, tidak mengatur secara khusus mengenai pembatasan luas lahan (baik minimum atau maksimum) untuk kegiatan usaha, termasuk di dalamnya usaha perkebunan, kecuali:

a. UUPA, tetapi hanya mengatur mengenai batas minimal tanah yang diberikan HGU dan persyaratan pemberian HGU yang luasnya di atas 25 (dua puluh lima) hektar.

b. UU Nomor 18 Tahun 2004 tentang Perkebunan, tetapi hanya mengatur bahwa pelaku usaha perkebunan sesuai dengan kepentingannya dapat memperoleh hak atas tanah, salah satunya dalam bentuk HGU, yang luas maksimum dan minimumnya ditetapkan oleh Menteri (Pertanian).

c. Baru pada Keputusan Menteri Kehutanan dan Perkebunan Nomor 107/KptsII/1999 yang kemudian ditinjau ulang dalam Keputusan Menteri Pertanian Nomor 357/Kpts/HK.350/5/2002 tentang Pedoman Perizinan Perkebunan, selanjutnya dicabut kembali dengan terbitnya Peraturan Menteri Pertanian Nomor 26/Permentan/OT.140/2/2007 yang memuat secara jelas dan tegas mengenai batas luas maksimum lahan usaha perkebunan. Terakhir ditinjau ulang dengan terbitnya Peraturan Menteri Pertanian Nomor 98/Permentan/OT.140/9/2013 tentang Pedoman Perizinan Usaha Perkebunan.

Beberapa pihak memberikan pendapat mengenai implikasi adanya pengaturan HGU dan luas lahan untuk usaha perkebunan tersebut. Menurut pandangan Achmad Mangga Barani, ${ }^{45}$ pengaturan pembatasan kepemilikan lahan

45 Achmad Mangga Barani, "Implikasi Pembatasan Kepemilikan Lahan Untuk Perkebunan Kelapa Sawit", disampaikan dalam Seminar "Sosialisai Revisi Permentan Nomor 26 Tahun 2007 tentang Izin usaha Perkebunan”, Hotel Puri Denpasar-Jakarta, 7 Nopember 2013. 
untuk usaha perkebunan, khususnya dalam Pasal 17 Permentan Nomor 98 Tahun 2013 dinilai tidak menimbulkan permasalahan yang berarti dalam pengembangan usaha perkebunan, utamanya perkebunan kelapa sawit. Meskipun Pasal 17 ayat (2) membatasi luas lahan untuk 1 (satu) perusahaan atau kelompok (group) perusahaan perkebunan, namun dalam Pasal 17 ayat (3) juga diatur pengecualiannya. Dimana pembatasan tersebut tidak berlaku untuk Badan Usaha Milik Negara, Badan Usaha Milik Daerah, Koperasi dan Perusahaan Perkebunan dengan status perseroan terbuka (go public) yang sebagian besar sahamnya dimiliki oleh masyarakat. Pengecualian ini sebelumnya juga telah diatur dalam Pasal 12 ayat (2) Permentan Nomor 26 Tahun 2007.

Namun demikian, dalam mengimplementasikan ketentuan kelompok (group) perusahaan perkebunan masih diperlukan kejujuran dan konsistensi dari pelaku usaha (perusahaan) dan aparatur pelaksana. Karena pengertian kelompok (group) dalam pasal 1 angka 8 Permentan 98 Tahun 2013 yang berbunyi:

Kelompok (group) Perusahaan Perkebunan adalah kumpulan orang atau badan usaha perkebunan yang satu sama lain mempunyai kaitan dalam hal kepemilikan, kepengurusan, dan/atau hubungan keuangan.

dinilai masih bersifat kualitatif sehingga bisa subyektif. Di samping itu, pengertian tersebut dinilai mengandung makna yang inklusif. Padahal kepemilikan, kepengurusan dan/atau hubungan keuangan mempunyai makna yang eksklusif.

Oleh karena itu, terkait pengaturan pembatasan kepemilikan lahan usaha perkebunan, yang harus menjadi perhatian para pemangku kepentingan perkebunan kelapa sawit justru ketentuan dalam Instruksi Presiden Republik Indonesia Nomor 10 Tahun 2011 tentang Penundaan Pemberian Izin Baru dan Penyempurnaan Tata Kelola Hutan Alam Primer dan Lahan Gambut yang kemudian diperpanjang berlakunya dengan Instruksi Presiden Republik Indonesia Nomor 6 Tahun 2013 serta Peraturan Menteri Negara Agraria/Kepala Badan Pertanahan Nasional Nomor 2 Tahun 1999 tentang Izin Lokasi, khususnya Pasal 4. Bukan pada pengaturan pembatasan lahan sebagaimana yang diatur dalam Permentan No. 98 Tahun 2013, khususnya Pasal 17. 
Dengan adanya Inpres Nomor 10 Tahun 2011 dan Inpres Nomor 6 Tahun 2013 justru yang menjadi penghambat bagi pengembangan lahan perkebunan kelapa sawit. Karena Inpres tersebut menginstruksikan para Gubernur, Bupati dan Walikota agar melakukan penundaan penerbitan rekomendasi dan izin lokasi baru pada kawasan hutan dan lahan gambut serta areal penggunaan lain berdasarkan Peta Indikatif Penundaan Izin Baru. Sementara ketentuan Pasal 4 Peraturan Menteri Negara Agraria/Kepala Badan Pertanahan Nasional Nomor 2 Tahun 1999 tentang Izin Lokasi memuat ketentuan:

Izin Lokasi dapat diberikan kepada perusahaan yang sudah mendapat persetujuan penanaman modal sesuai ketentuan yang berlaku untuk memperoleh tanah dengan luas tertentu sehingga apabila perusahaan tersebut berhasil membebaskan seluruh areal yang ditunjuk, maka luas penguasaan tanah oleh perusahaan tersebut dan perusahaanperusahaan lain yang merupakan satu group perusahaan dengannya tidak lebih dari luasan sebagai berikut:

c. Untuk usaha perkebunan yang diusahakan dalam bentuk perkebunan besar dengan diberikan Hak Guna Usaha:
1) Komoditas tebu
: 1 propinsi
: 60.000 hektar Seluruh Indonesia : 150.000 hektar
2) Komoditas lainnya
: 1 propinsi
: 20.000 hektar Seluruh Indonesia : 100.000 hektar.

Pengaturan pembatasan kepemilikan lahan usaha perkebunan dalam Instruksi Presiden Republik Indonesia Nomor 10 Tahun 2011, Instruksi Presiden Republik Indonesia Nomor 6 Tahun 2013, dan Peraturan Menteri Negara Agraria/Kepala Badan Pertanahan Nasional Nomor 2 Tahun 1999 diatas dinilai dapat menimbulkan implikasi yaitu: 1) Pengembangan perkebunan kelapa sawit, khususnya di remote area yang memerlukan prasarana dan infrastruktur yang cukup besar akan sulit terbangun; 2) Penurunan produksi kelapa sawit akibat tidak dilakukannya peremajaan tanaman kelapa sawit oleh perusahaan besar yang areal Hak Guna Usahanya telah berakhir dan luasnya melebihi 100.000 hektar; 3) Indonesia kehilangan momentum dalam mengembangkan produk perkebunan yang mempunyai daya saing yang tinggi. 
Hal tersebut di atas didasarkan pada kenyataan, kelapa sawit sangat sesuai ditanam di lahan yang tersebar di beberapa wilayah Indonesia. Kelapa Sawit Indonesia juga dinilai Pro-Growth, Pro-Job, Pro-Poor, Pro-Devisa, ProEnvironment. Di samping itu, sesuai dengan The Tripple Bottom Line, yaitu 3 P: People, Planet, Profit yang pertama sekali diperkenalkan oleh Freer Spreckley pada tahun 1981 dalam artikel: "Social Audit - A Management Tool for Cooperative Working”. Sehingga kelapa sawit Indonesia memberikan peran penting baik bagi kepentingan Nasional Indonesia maupun dunia. Bagi kepentingan Nasional Indonesia antara lain: 1) Sumber pendapatan dan lapangan kerja. Lebih 3,72 juta Kepala Keluarga di Indonesia terserap di usaha on-farm kelapa sawit. 2) Penanggulangan kemiskinan. 3) Pengembangan wilayah, termasuk wilayah perbatasan. 4) Sumber pendapatan ekspor non migas. Nilai ekspor minyak sawit lebih besar dari nilai ekspor hasil pertanian di luar minyak sawit. Dimana pendapatan ekspor minyak sawit lebih dari US\$ 17,3 Milyar dan penerimaan dari Pajak Ekspor sebesar Rp 28,3 Triliun. 5) Mendukung industri dalam negeri. 6) Sumber pangan (minyak goreng) dan energi (biofuel). Sementara bagi kepentingan dunia, antara lain: 1) Kelapa sawit merupakan tanaman tahunan yang diproduksi di negara berkembang/tropis. Sedangkan minyak nabati lainnya merupakan tanaman semusim. 2) Minyak kelapa sawit merupakan salah satu minyak nabati yang paling efisien dari segi produktivitas dan biaya produksinya dibandingkan dengan minyak nabati lainnya, misalnya, kedelai, bunga matahari, rapeseed, dan kelapa. 3) Luas areal minyak nabati dunia, yaitu a) Kedelai dunia: 93 juta hektar; b) Rapeseed: 27 juta hektar; c) Bunga Matahari: 23 juta hektar; dan d) Kelapa Sawit (TM): \pm 15 juta hektar (tahun 2011). 4) Persentase produksi minyak nabati dunia: a) Palm dan Palm Kernel Oil: 38,0\%; b) Rape Oil :15,9\%; c) Sunflower Oil: 8,3\%. 5) Total produksi minyak sawit (CPO) Indonesia dan Malaysia sebesar $85.3 \%$ dari produksi dunia. 6) Sejak tahun 2006, Indonesia menjadi negara produsen minyak sawit terbesar di dunia. 7) Saat ini minyak sawit dikonsumsi lebih dari 160 negara di dunia. 8) Sejak tahun 2005, pangsa pasar minyak sawit menggeser pangsa minyak kedelai. Sebelumnya pangsa pasar kedelai merupakan yang terbesar di antara minyak nabati. 
Adapun potensi yang terkandung dalam perkebunan kelapa sawit, antara lain: 1) Minyak kelapa sawit merupakan minyak makan, oleo kimia, dan sumber energi. 2) Limbah padat dan cair dapat digunakan sebagai pakan ternak, pupuk, dan energi. 3) Kayu kelapa sawit bekas peremajaan dapat digunakan sebagai bahan baku industri perkayuan. 4) Sebagai sumber pangan dalam pengembangan tanaman pangan intercrop, yaitu jagung dan palawija, selama kanopi belum menutup.

\section{PENUTUP}

Dengan demikian, menurut pandangan saya, pengaturan mengenai persyaratan dan pembatasan luas lahan untuk usaha perkebunan dalam peraturan pelaksana suatu undang-undang diperbolehkan dan tidak bertentangan dengan peraturan perundang-undangan yang ada. Namun, yang terpenting pengaturan tersebut harus memperhatikan hal-hal sebagai berikut:

a. Harus ditujukan untuk mencapai kemakmuran rakyat yang sebesar-besarnya, dalam arti kebahagiaan, kesejahteraan dan kemerdekaan dalam masyarakat dan Negara Hukum Indonesia yang merdeka, berdaulat, adil dan makmur sesuai ketentuan Pasal 2 ayat (2) dan (3) UUPA.

b. Harus dilaksanakan untuk menciptakan kepastian dan perlindungan hukum serta keadilan dan kemakmuran bagi seluruh rakyat Indonesia sesuai dengan ketentuan Pasal 2 TAP MPR RI Nomor IX/MPR/2001 tentang Pembaruan Agraria dan Pengelolaan Sumber Daya Alam.

c. Di samping itu, harus dilakukan guna menjamin pemilikan, penguasaan, penggunaan dan pemanfaatan tanah secara berkeadilan sebagaimana diamanatkan oleh UU Nomor 18 Tahun 2004 tentang Perkebunan.

\section{DAFTAR PUSTAKA}

\section{BUKU}

Harsono, Boedi. Hukum Agraria Indonesia. Cetakan XIX. Jakarta: Djambatan, 2008. 
Rajagukguk, Erman, et al.. Masalah Tanah Di Indonesia Dari Masa Ke Masa. Jakarta: Lembaga Studi Hukum Ekonomi Fakultas Hukum Universitas Indonesia, 2007.

Swasono, Sri-Edi dan Fauzie Ridzal. Penyunting. Satu Abad Bung HattaDemokrasi Kita, Bebas Aktif, Ekonomi Masa Depan. Jakarta: UI-Press, 2006.

\section{PERATURAN PERUNDANG-UNDANGAN}

Indonesia. Undang-Undang Dasar 1945.

Undang-Undang tentang Peraturan Dasar Pokok-Pokok Agraria. UU No. 5 Tahun 1960, LN No. 104 Tahun 1960, TLN No. 2043.

-. Undang-Undang tentang Perkebunan. UU No. 18 Tahun 2004, LN No. 85 Tahun 2004, TLN No. 4411.

.Undang-Undang tentang Penanaman Modal. UU No. 25 Tahun 2007, LN No. 67 Tahun 2007, TLN No. 4724.

Peraturan Pemerintah tentang Hak Guna Usaha, Hak Guna Bangunan dan Hak Pakai Atas Tanah. PP No. 40 Tahun 1996. LN No. 58 Tahun 1996, TLN No. 3643.

Instruksi Presiden Republik Indonesia Nomor 10 Tahun 2011 tentang Penundaan Pemberian Izin Baru dan Penyempurnaan Tata Kelola Hutan Alam Primer.

Instruksi Presiden Republik Indonesia Nomor 6 Tahun 2013 tentang Penundaan Pemberian Izin Baru dan Penyempurnaan Tata Kelola Hutan Alam Primer.

Keputusan Menteri Kehutanan dan Perkebunan No. 107/Kpts-II/1999 tentang Perizinan Usaha Perkebunan.

Keputusan Menteri Pertanian Nomor 357/KPTS/HK.350/5/2002 tentang Pedoman Perizinan Usaha Perkebunan.

Peraturan Menteri Pertanian Nomor 26/Permentan/OT.140/2/2007 tentang Pedoman Perizinan Usaha Perkebunan.

Peraturan Menteri Pertanian Nomor 98/Permentan/OT.140/9/2013 tentang Pedoman Perizinan Usaha Perkebunan.

\section{INTERNET}

HP, Arimbi dan Emmy Hafild, "Membumikan Mandat Pasal 33 UUD 45", $<$ http://www.pa-cific.net.id/ dede_s/Membumikan.htm>, diakses $16 \mathrm{Mei}$ 2009. 


\section{MAKALAH}

Barani, Achmad Mangga. "Implikasi Pembatasan Kepemilikan Lahan Untuk Perkebunan Kelapa Sawit". Disampaikan dalam Seminar "Sosialisasi Revisi Permentan Nomor 26 Tahun 2007 tentang Izin usaha Perkebunan”, Hotel Puri Denpasar-Jakarta, 7 Nopember 2013. 